\title{
МЕТОДЫ ИССЛЕДОВАНИЯ РАЗВИТИЯ РЕЧИ МЛАДШИХ ШКОЛЬНИКОВ НА УРОКАХ ЛИТЕРАТУРНОГО ЧТЕНИЯ
}

\section{METHODS FOR RESEARCHING THE SPEECH DEVELOPMENT OF YOUNGER SCHOOL PERSONS IN THE LITERARY READING LESSONS}

\section{N. Safarova \\ L. Mamedova}

Summary: In this article we present the essence of speech and speech development. We also identified tutorial methods of speech development for elementary students in literature readings classes. We also reviewed the Federal state standard and the Federal law on education. The research facility was MEI SGES №15 in Neryungri town. For the diagnostic study, we used the methods for determining the active dictionary, for determining the passive dictionary of Nemov R. S. We applied complex diagnosis for students. The research involved 46 third-grade students. In conclusion we would like to come up with work on speech development for elementary students in literature readings classes. Besides, after this research we will be able to develop teaching-aid package of literature readings classes for speech development and teaching elementary students essay writing techniques.

Keywords: elementary students, speech, speech development, literature readings, diagnosis, tutorial methods, research, study. $\mathrm{y}$ чителя начальных классов, несут ответственность за развитие речи, к тому же они не только учат детей читать и писать, но также и выбирать точные слова, свободно и правильно строить предложения, владеть интонациями, дыханием и тд.

В современном мире развитие речи у учащихся является актуальной задачей, и в первую очередь данная задача решается на уроках русского языка и литературного чтения. Федеральный государственный образовательный стандарт начального общего образования (ФГОС НОО, введенный в действие с 1.01.2010 г.) и Федеральный закон «Об образовании в Российской Федерации» (Ф3 № 273, введенный в действие 29.02.2012 г.) выделяет то, что учащиеся начальной школы должны обладать различными речевыми навыками, в том числе сознательно уметь выстраивать речевые высказывания в соответствии с задачами общения, и также уметь писать и списывать текста.

В современном мире учащиеся начальной школы
Сафарова Нармин Абид кызы

Технический институт (филиал) Северо-Восточный федеральный университет имени М.К. Аммосова в Нерюнгри narminag_99@mail.ru

Мамедова Лариса Викторовна

к.п.н., доцент, Технический институт (филиал) СевероВосточный фредеральный университет имени М.К. Аммосова в Нерюнгри larisamamedova@yandex.ru

Аннотация: В данной статье нами была раскрыта сущность понятия «речь», речевое развитие, также нами были выявлены методические приемы развития речи младших школьников на уроках литературного чтения, также была проведена опытно-экспериментальная работа, цель которой было апробировать методические приемы по развитию речи младших школьников на уроках литературного чтения. База нашего исследования МБОУ СОШ № 15 г. Нерюнгри, в исследовании нами была использована комплексная диагностика учащихся. В исследовании приняли участие учащиеся третьих классов в количества 46 человек. Также по завершению проведенных нами исследований, мы сделали выводы, и предлагаем провести работу по развитию речи у детей младшего школьного возраста на уроках литературного чтения. Также наше исследование состоит в том, что в будущем мы сможем разработать комплекс уроков литературного чтения с целью развития речи, обучения сочинениям на литературном материале для младших школьников.

Ключевые слова: младшие школьники, речь, развитие речи, литературное чтение, диагностика, методика, исследования.

испытывают трудности в правильном формулировании основной мысли, и высказывании своего мнения. Нами была рассмотрена письменная речь, и мы выявили трудности у учащихся начальной школы. В большинстве случаев они возникают от не сформированности умений правильно составлять текста-рассуждения. Большая часть обучающихся не умеют развивать мысль в тексте, выражать свое отношение к главным героям литературных произведений.

Таким образом, мы можем сформулировать проблему в виде вопроса: как методически правильно построить работу по развитию речи младших школьников на уроках литературного чтения.

Далее мы изучили научно-педагогическую литературу, что позволило нам, рассмотреть понятия слова «речь», речевое развитие.

Общая психология, рассматривает понятия «речь», как «исторически сложившаяся в процессе материаль- 
ной преобразующей деятельности людей форма общения, опосредованная языком» [8, с. 252].

Научные деятели И.А. Зимняя и М.Р. Львов отмечают, что понятия «речь» и «язык» не тождественны. И.А. Зимняя, исследуя вопрос соотношения понятий «язык» и «речь», заключает, что язык - это средство, а речь - способ формирования и выражения мысли в речевой деятельности. «Язык - это система вербальных знаков, относительно независимая от индивида, служащая для цели коммуникации, формирования мыслей, закрепления и передачи общественно-исторического опыта. Язык это многоуровневая система со своими требованиями и ограничениями по всем уровням» $[2$, с. 67]

По своей сути речевая деятельность является интеллектуальным видом деятельности. Это определено природой и свойствами предмета речевой деятельности и основных ее целей. Адекватное отображение определенного мысленного содержания с помощью системы знаков языка и невербальных знаков является одной из главных задач речевой деятельности.

В начальной школе учащиеся активно овладевает монологической речью, приобретают умения, необходимые для построения текстов публицистического, официально-делового (большей частью учебно- научного) стиля речи.

После того как мы рассмотрели понятие слова «речь» и речевая деятельность, мы начали изучать научно-педагогическую литературу, чтобы установить связь между речью и мышление. По итогу мы определили, что ведущим является мышление, а не речь. Мышление и речь возникают совместно на основе практики. Также речь и мышление совместно применяются в различных формах и видах. Через познавательную деятельность, у ребенка формируется способность к мышлению.

Также нами были рассмотрены методические приемы обучения младших школьников по развитию речи на основе литературного материала.

При работе на уроках литературы, детей учат пересказывать текст, писать эссе и сочинения, остановимся подробно над написанием сочинений.

Для того, чтобы учащийся грамотно написал сочинение по литературе педагог должен научить его соблюдать три основных этапа:

1. Накопление материала (наблюдение, чтение, анализ художественного произведения и т.д.);

2. Отбор и расположение материала (обсуждение, выделение главного, составление плана работы);

3. Речевое оформление (составление связного текста, его письменного оформление, проверка, редактирование).
Также для того, чтобы учащийся смог обладать грамотной и правильно поставленной речью, на уроках литературного чтения, проводится анализ художественного текста, он включает в себя конкретную операцию, которую совершает читатель в процессе понимания идеи произведения. Данный вид деятельности очень полезен, в начальной школе, так как с помощью него учитель может вовремя направить и скорректировать восприятие обучающихся.

К анализу художественного текста, также есть требования:

1. Целенаправленность. Цель анализа, должна состоять в углублении восприятия прочитанного;

2. Анализ текста должен производится только после целостного и эмоционального восприятия, прочитанного;

3. Также должен быть соблюдаться учет возрастных и индивидуальных особенностей читателя;

4. Анализ должен отвечать потребности ребенка разобраться в прочитанном;

5. Также необходимо научить анализировать не саму жизненную ситуацию, описанную в произведение, а то, как ее изображает автор;

6. В конце анализа обязательно должен быть проведен синтез.

Нами были выявлены речевые умения, формируемые в процессе обучения младших школьников сочинениям на литературном. Речевые умения представлены в таблице 1.

Таблица1

Речевые умения, формируемые в процессе обучения младших школьников сочинениям на литературном

$$
\text { материале }
$$

\begin{tabular}{|l|l|}
\hline $\begin{array}{l}\text { Отзыв 0 } \\
\text { прочитанной }\end{array}$ & $\begin{array}{l}\text { ученик должен научиться составлять развернутые } \\
\text { высказывания, отражающие личное отношение к про- } \\
\text { изведению и его главным героям, уметь обосновывать } \\
\text { свое отношение у прочитанному. }\end{array}$ \\
\hline Аннотация & $\begin{array}{l}\text { ученик должен научиться выделять главное в произ- } \\
\text { ведении, уметь кратко излагать основное содержание, } \\
\text { строить текст по заданному образцу использовать при } \\
\text { составлении текста разные способы его сжатия. }\end{array}$ \\
\hline $\begin{array}{l}\text { Описание } \\
\text { героев } \\
\text { произведения }\end{array}$ & $\begin{array}{l}\text { ученик должен научиться на основе информации о } \\
\text { герое, заданной в произведении, уметь описать внеш- } \\
\text { ность, особенности поведения, качества героя, уметь } \\
\text { перестроить текст по-новому таким образом, чтобы } \\
\text { дать оценку героя произведения. }\end{array}$ \\
\hline $\begin{array}{l}\text { сравнение } \\
\text { героев } \\
\text { произведений }\end{array}$ & $\begin{array}{l}\text { ученик должен научиться подбирать материал о } \\
\text { действующих лицах, уметь строить текст на сравнении по выделенным характеристикам, уметь фор- } \\
\text { гелировать самостоятельные выводы и критически } \\
\text { оценивать героев произведения. }\end{array}$ \\
\hline
\end{tabular}


Опытная работа была проведена в 3 классах МБОУ СОШ № 15 г. Нерюнгри. В данной работе приняли участие обучающиеся двух классов в количества 46 человек. На констатирующем этапе была проведена диагностическая работа, состоявшая их двух методик.

1. Методика определения активного словарного запаса (Немов Р. С.) [3];

2. Методика определения пассивного словарного запаса (Немов Р. С.) [3].

Таблица 2

Результаты методики определение активного словарного запаса Немов Р. С.

\begin{tabular}{|c|c|c|}
\hline Уровень & Баллы & $\%$ \\
\hline Очень высокий & 0 & 0 \\
\hline Высокий & 8 & 17 \\
\hline Средний & 26 & 56 \\
\hline Низкий & 8 & 17 \\
\hline Очень низкий & 4 & 8 \\
\hline
\end{tabular}

По результат можем сделать вывод, что не все из учащихся справились хорошо. В этом протоколе была отмечена частота употребления различных частей речи, сложных предложений с союзами и вводных конструкций, что свидетельствует об уровне развития его речи. только 8 (17\%) детей, смогли использовать в своем рассказе практически все части речи. Дети, которые получили низкие баллы, рассказ по картинке составляли неуверенно, практически не составляли предложения или составляли предложения из двух трех слов. Учащиеся получившие низкие баллы, плохо смогли дать полное описание по картинке.

Завершающая диагностика была по определению пассивного словарного запаса учащихся. Результаты по диагностике представлены в таблице 4.

Таблица 3

Результаты методики определение пассивного словарного запаса Немов Р.С.

\begin{tabular}{|c|c|c|}
\hline Уровень & Баллы & $\%$ \\
\hline Очень высокий & 0 & 0 \\
\hline Высокий & 7 & 15 \\
\hline Средний & 28 & 60 \\
\hline Низкий & 11 & 23 \\
\hline
\end{tabular}

По результат можем сделать вывод, что не все из учащихся справились хорошо. Не каждый ребенок смог подобрать подходящее по смыслу к слову, найти пару слов, которая составляет с предложенным словом единую группу. Это свидетельствует о необходимости у учащихся, повышать уровень в активном словарном запасе, и учить детей подбирать слова, которые относятся в одну обобщающуюся их группу.

По результатам проведенных диагностик, можно сделать вывод, что большинство обучающихся обоих классов находятся на низком уровне знаний в данном аспекте, то есть испытывают затруднения при определении обобщающих понятий, не всегда могут составить связный текст по выданной им картинке. Нами были отмечены серьезные затруднения в смысловой организации высказываний. Выполнение творческих заданий оказалось для детей практически недоступным. Был сделан вывод, что дети не владеют навыками самостоятельного составления описания по картинке. Для их высказываний характерны крайняя бедность используемых языковых средств, наличие грубых ошибок, нарушающих связность повествования. Таким образом, полученные результаты подтвердили необходимость организации формирующего этапа эксперимента, направленного на развитие речи у младших школьников.

Также по результатам проведенной диагностике, можно сделать некоторые рекомендации по развитию речи у детей младшего школьного возраста на уроках литературного чтения. Для того чтобы повысить активный словарь детей, нужно объяснить им каждое непонятное для них слово, и рассказывать детям об определении этого слова. На уроках чтения, необходимо в процессе урока, спрашивать детей значение какого-нибудь слова, на выбор учителя. Также педагог может урок чтения начинать с сюжетных картинок и разговора о них, начинать опрос каждый урок в алфавитном порядке, чтобы у каждого ребенка была возможность потренироваться в составлении рассказов с помощью сюжетных картинок. Следует уделить внимание и практической работе, как можно чаще задавать детям задания связанные с составлением письменных текстов-рассуждений, с помощью такой практики учащиеся не только будут практиковаться в использовании в тексте новых слов, а также будут учиться писать красивые текста. После написание учениками их практической работы, а именно мини-сочинений, можно попросить учеников прочитать для одноклассников, что они написали и чтобы каждый мог поделиться своим мнением. Это будет хорошая практическая деятельность, через, которую дети научаться, не только развивать свою речь, но также наладят коммуникационное общение.

Статья выполнена под руководством научного руководителя: к.п.н., дочента Мамедовой Л.В. 


\section{ЛИТЕРАТУРА}

1. Бахтин М.М. Эстетика словесного творчества. - М.: Искусство, 2011. - 424 с.

2. Зимняя И.А. Лингвопсихология речевой деятельности. - М.: НПО

3. «МОДЭК», 2001. -432 c.

4. Немов Р.С. Психология: Учеб. для студ. Высш. Пед. Учеб. заведений: В 3 кн. - 4-е изд. - М. : ВЛАДОС, 2001. - 640 с.

5. Леонтьев А.А. Язык, речь, речевая деятельность. - М.: Просвещение, 2006. - 214 с.

6. Львов М.Р. Методика развития речи младших школьников. - М.: Просвещение, 2011. - 176 с.

7. Ткаченко Л.В. Психолого-педагогические и психолингвистические особенности развития речи младших школьников в период обучения грамоте // Концепт. - 2015. - №7 - $6 c$.

8. Щерба Л.В. Избранные работы по русскому языку. - М.: Артик, 2005. - 68 с.

9. Ярцева В.Н. Лингвистический энциклопедический словарь. - М. : Советская энциклопедия, 2002. - 682 c.

() Сафарова Нармин Абид кызы (narminag_99@mail.ru), Мамедова Лариса Викторовна (larisamamedova@yandex.ru) Журнал «Современная наука: актуальные проблемы теории и практики»

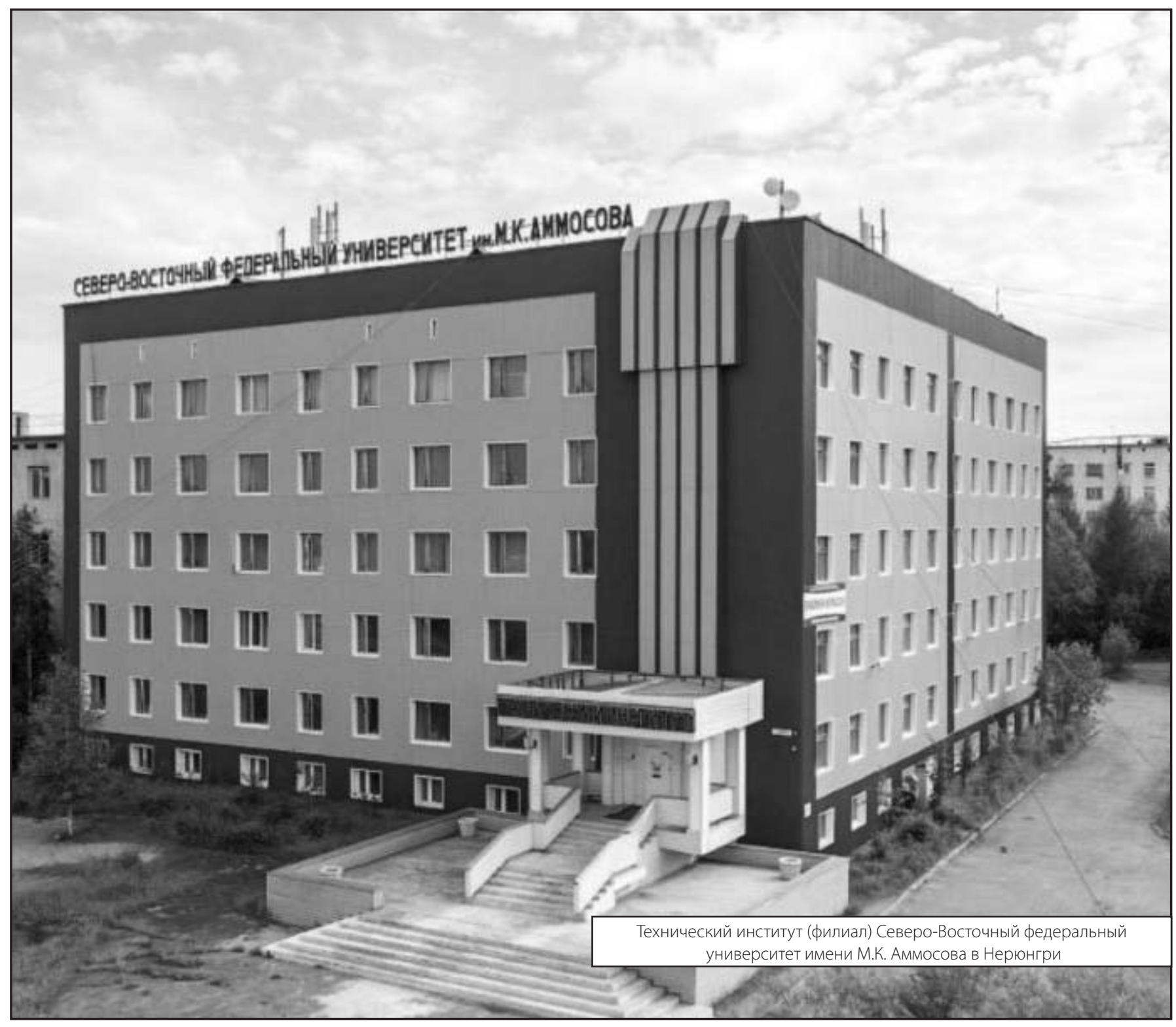

